DOI: $10.33067 /$ SE.1.2019.01

\author{
Michal Šejvl`
}

\title{
European Identity in Times of Crises
}

\begin{abstract}
This essay tries to discuss three possible models of common European identity based on shared political values, shared economic interests and shared cultural heritage in our actual situation when Europe is suffering from many crises or their aftermaths (Eurozone crisis, migration crisis or Brexit crisis). The first non-exclusive "thin" identity model is based on many essentially contested concepts (in the essay demonstrated on the concept of human dignity) and its major weakness lies in the fact that many of these values are eroding in our practices, not only in the "new" EU member states. The approach based on shared pragmatic interests does not produce strong moral commitments, but the real problem of this model is that since the beginning of 1970s one of the truly European "innovations" - its post-war model of welfare state - is put into question (The essay tries to demonstrate it using the theory of Wolfgang Streeck). The common cultural heritage model that can produce "thick" identity is on the first sight the most difficult to build because of the almost insurmountable plurality between European cultures. However, the shared culture can produce cosmopolitan "identity in diversity", but only if material conditions for the creation of this "fragile" or "delicate" identity model are created in some form of reinvented welfare state that could liberate us from many fears we have.
\end{abstract}

Key words: European Identity, European Union Crisis, Migrations, Brexit, Eurozone

\section{Introduction}

Exactly ten years ago I published a short article on the relationship between EU citizenship and European identity as a follow-up of

${ }^{\star}$ Michal Šejvl-Czech Academy of Sciences, Prague, e-mail: sejvl@ilaw.cas.cz, ORCID: 0000-0002-8278-1730. 
a conference held in Budapest premises of Hungarian Institute for Legal Studies. ${ }^{1}$ So many things has changed since those times that 2008 can be retrospectively perceived almost as an "European idyll": It is true that the Constitution of Europe was rejected by French and Dutch referenda in 2005 (a continuation of a trend starting with Danish 1992 referendum and ending-up with Brexit? One of the first signs of clivage between "old" and "new" member states taking into account the role the "Polish plumber" had played in French campaign at that time?), but Lisbon Treaty "kept and transferred" many of the Constitution's novelties to EU acquis (and Irish had to vote again - a sign how political elites perceive "the voice of the people"?). In 2008 all of our present day crises seemed to be far away: American sub-prime mortgage loans crisis (soon turned to a financial crisis, Eurozone crisis and Greek catastrophe) has only started and almost nobody expected the massive influx of immigrants culminating in 2015 or 2016 Brexit referendum. Writing about European identity today when we still face at least "echoes" of all of the above-mentioned crises, looks like an effort that is as hopeless as naïve at its best. Nevertheless in this short essay I try to discuss three approaches to conceptualization of European identity: Shared political values, shared economic interests and a shared culture.

\section{Shared Values}

The list in Art. 2 of TEU can be used as an inspiration to find out which values can be the shared European political values - human dignity, freedom, democracy, equality, rule of law, human rights, pluralism, non-discrimination, tolerance, justice, solidarity. It is not necessary to be an expert to realize quickly that almost every item in the list is a problem in itself - not to mention relationships between them (e.g. between human rights and democracy). The example of human dignity can be instructive: In spite of the fact that various human rights documents mention inherent dignity as a foundation of all human rights (e.g. preambles of both 1966 UN Covenants), we can legitimately ask what conception of human dignity is at issue. If it is the Christian concept of dignity of person understood as an assignment or "vocation" that is expressed e.g. in encyclical Evangelium vitae from 1995, then abortions, IVF or euthanasia are clearly against human dignity. If it is the Kantian concept of moral autonomy that inter alia prohibits treating moral subjects (including oneself) like

1 M. Šejvl, European Identity and European Citizenship: the Case of Missing Polis?, "International Journal of Public Administration in Central and Eastern Europe", no. 2/2008, pp. 49-56. 
means (and not as ends in itself), then not only famous issues like "killing games" ${ }^{\prime 2}$ or consensual sadomasochistic sex ${ }^{3}$ can be qualified as being contrary to human dignity, but also heavy smoking or alcohol drinking (because smoker or drinker treats herself as a means for her own pleasure) or exhaustive and mechanical manual work of a worker on a production line (because she is effectively reified). If it is Robert Alexy's concept of human dignity based on double triad of intelligence, sentience and consciousness (that includes in itself cognitive, volitive and normative reflexivity), ${ }^{4}$ then new-born infants or people suffering by dementia that do not possess these qualities probably do not have human dignity either. Moreover, the problem does not only lie in differences between theoretical conceptions of human dignity, but also in our legal practices invoking human dignity: We usually assume that people are equal in their dignity, but at the same time we accept that possible violations of human dignity can be qualified differently among different groups of persons - e.g. according to the Czech law a politician, singer or journalist have to live with the fact that such violations are qualified less severely in comparison to others because politicians, singers or journalists have voluntarily exposed themselves to the public; according to the British law attacks on dignity of a film actor (e.g. critique of her look) are qualified more severely (because the look is an essential component of actor's profession) than attacks on others. This example shows that the reasoning justifying the difference in treatment can be almost the same (publicly exposed figures can be treated differently than "common people" because of their public engagement), but with the opposite results. The conclusion on the problem of human dignity in my opinion can be that human dignity itself is an essentially contested concept within which various different and sometimes conflicting conceptions and practices of dignity can "live together". 5

Similar "deconstructions" can be of course easily made with other items on Art. 2 list like human rights ${ }^{6}$ or democracy. ${ }^{7}$ But does it mean

2 See: C-36/02 Omega Spielhallen- und Automatenaufstellungs-GmbH v. Oberbürgermeisterin der Bundesstadt Bonn [2004] ECR I-09609.

3 See: Laskey, Faggard and Brown v UK (1997) 24 EHRR 39.

4 R. Alexy, Lidská di̊stojnost a princip proporcionality (Human Dignity and Proportionality Principle), "Právník", no. 11/2015, p. 873 et seq.

5 See: e.g. P.-A. Rodriguez, Human Dignity as an Essentially Contested Concept, "Cambridge Review of International Affairs", no. 4/2015, pp. 743-756.

${ }^{6}$ I tried to argue that concept of human rights is essentially contested in M. Šejvl, Lidská práva jako diskursioní pojem (Human Rights as an Essentially Contested Concept), "Právník", no. 6/2017, pp. 473-500.

7 On various models of democracy see: e.g. D. Held, Models of Democracy, 3rd edition, Cambridge 2006. 
that these values are, for its essentially contested character, useless as a possible foundation of European identity? I would rather say that it is exactly their essentially contested character that makes them suitable "candidates" for grounding some form of belonging, because these values are sufficiently "flexible", when they mean "many things to many men." The problem however starts when the questioning and revealing of essentially contested character of these values come up as a "hot" political issue of the day - like e.g. whether rule of law standards are endangered in a particular member state or not. Therefore these values can serve us very well to ground our belonging in "sunny days", but not in times of crisis.

Another problem with these values is that they are usually perceived as universal. Although no one contests that these values have their roots in Western European tradition and for a long time they have been typical for EU member states (e.g. requirements of democracy, human rights and rule of law were among basic requirements for entry of Central and Eastern European countries to EU), these values are not obviously unique for Europe - it is possible that United States can be a good example of the country sharing these values too. Therefore these values create a "weak" model or "thin" conception of identity. This is the reason why some people add to these values such items that can be typical only for the particular model of European integration. The good example could be the concept of "constitutional patriotism" of Jürgen Habermas. ${ }^{8}$ Very briefly: Central to this concept is the idea of inclusion of all citizens with equal rights in a republican and democratic post-national institution which is itself based on constitutional values like the doctrine of material Rechtsstaat. This institution extends borders of nation-states and this institution also helps to overcome the differences in many nation-states using procedures for its citizens to participate on the decision-making of the institution. This concept is formal because it does not possess any cultural or historical content - on the other hand, different national cultures or ethnic and cultural bonds are perceived as divisive elements and not as constitutive elements. This "patriotism without nationalism" is procedural because the post-national institution offers its citizens procedures for participation - this is the reason why, inter alia, Habermas is also a strong propagator of referendum at the level of EU. From this point of view the EU must sooner or later overcome the so-called "democratic deficit" of its institutions and have to transform to federation. The disadvantage of this concept is that it is also a model of minimal identity based rationally on law and democracy (meeting each other in the constitution) - e.g. we

8 For the brief version of this Habermas' concept see: e.g. J. Habermas, Toward a Cosmopolitan Europe, "Journal of Democracy", no. 4/2003, pp. 86-100. 
could ask, who can fall in love with constitution? The more so in times of crises we are living in when e.g. Brexit has shown us that process of European integration is not at all an irreversible process of "deepening and widening", but can be stopped and returned - to the dismay of many who dreams of a European federation. The fact that the triggering mechanism of Brexit was referendum (tool of participatory democracy that was in fact ignored in previous Danish or Irish cases) propagated inter alia by constitutional patriotism adds a grain of irony to the whole issue.

However, the biggest problem of shared European political values is in my opinion the fact that many of these values are currently eroding in some member states regardless of which conceptions of these values we have and sometimes not in direct connection with the above-mentioned crises. I do not want to talk about possible erosion of rule of law in "new" member states, e.g. in Hungary where the constitutional judiciary probably submitted itself to politics ${ }^{9}$ and the ruling party has probably monopolized the whole public sphere without any foreseeable possibility of future reversal (a phenomenon almost unimaginable in Europe after the fall of communism!). Instead I would like to point out that different erosions of rule of law or human rights can be perceived also in one of the EU founding member states - France. After 2008 for the first time and more massively after Paris 2015 terrorist attacks (that do not have any direct connection to financial or migration crises) France has adopted measures limiting many human rights without the possibility of full judicial review as a part of its état d'urgence legislation. These measures included retention de sécurité (if a person is considered to be dangerous, she can be deprived of her liberty without necessity to prove her culpability), assignation à résidence (minister of inferior or prefect can order a person not to leave her place of residence), perquisitions administratives (in fact a house search without previous judicial warrant) etc. There are several features of these measures that are striking - these measures can be ordered by administrative authorities and not by judicial power; the review of these measures is possible only ex post and is more or less only formal and done usually by administrative judiciary (ordre administrative), not by "ordinary" judicial power (ordre judiciaire - with the exception of perquisitions administratives

9 See: e.g. Z. Szente, F. Gárdos-Orosz, Fudicial deference or political loyalty?: The Hungarian Constitutional Court's role in tackling crisis situations, in: New Challenges to Constitutional Adjudication in Europe. A Comparative Perspective, eds. Z. Szente, F. Gárdos-Orosz, London 2018, pp. 89-110. In this context it is maybe interesting to note that English judiciary was perceived as politically strongly connected with conservative party till the end of 1960s - see: R. Stevens, The English Fudges. Their Role in the Changing Constitution, Oxford 2005, chapters 1 and 2. 
that are reviewed by juge de la liberté et de la détention) $;{ }^{10}$ the "preventive character" of these measures (their use depends on considerations of dangerousness of a person, her suspicious activity etc.) that leads to situations that measures can be extended for a very long time (in contrast to "classical" punishments that are based on proven culpability and are limited in time). These measures are of course justified in the exceptional state of imminent terrorist threat as in état d'urgence imposed in the end of 2015 - but the extension of these measures beyond état d'urgence in autumn 2017 (when similar measures, sometimes differing only in their names, has become part of droit commun) signals that various rule of law "components" can be in danger, not to mention the fact that these measures affects mainly Muslim population (e.g. sometimes the only qualification for imposition of such a measure was that an affected person had converted to Islam) and various ecological, antifascist or anti-capitalist activists (e.g. those who manifested against reforms of loi de travail). ${ }^{11}$ No wonder that some commentators are talking about steps towards disintegration of rule of law, about "general confusions" between exceptional and ordinary (droit d'exception and droit commun), between administration and penal judiciary, between prevention and repression etc. ${ }^{12}$ It is true that such measures are not as "dangerous" for rule of law as e.g. attacks on the independence of judiciary elsewhere or the monopolization of the whole public life by one party, but they are definitely a step towards questioning or putting in doubt one of the most important value lawyers are usually proud of.

The last point on erosion of political values and populism: It is widely assumed that one of the main threats to these values is populism. But is it possible to establish any traits or attributes that are typical for populism? Is populism politics that propose a simple solution to complex problems? If so, much of political agenda of 1990s (at least in the Czech Republic) asserting that "market can solve all our problems" was populist. Is populism closely attached to ethnos rather than to demos? If so, Brexit campaigners were not populists, because they attracted significant proportion of British voters of Indian or Asian descent, and pro-EU governments in Baltic states are populists, because they consistently deny citizenship to their Russian minorities. Is populism against checks of political power enabling

10 See: e.g. information on the research, how especially administrative judges only formally reviewed these exceptional measures in S. Faure, P. Alonso, Etat d'urgence: des travers dans l'Etat de droit, "Libération", 21st of June 2017.

11 Ibidem.

12 See: e.g. the interview with College de France honorary law professor Mireille Delmas-Marty Nous sommes passés de l'état de droit à l'état de surveillance, "Le Monde", 13th of October 2017. 
populists to radically change the political landscape? If so, then Matteo Renzi, who wanted to abolish Senate and thus promote the effectiveness of governance, can be labelled as populist. And if populism means only protest against dominant status quo, then every politician questioning e.g. financialisation of social policy or erosion of welfare state is populist. Does it mean that if you do not endorse current values of Brussels elites, you are populist? If so, then what is the value of pluralism included in Art. 2 list? Does the label of "populism" has any analytical value at all?

To conclude this part: Shared political values can offer us a weak model of rather non-exclusive "thin" identity that probably cannot work well in times of crises revealing the essentially contested character of these values. Because these values are rather abstract, they can in my opinion hardly win "hearts and minds" of majority of people. But I think that the main problem is that current situation in various EU member states shows that we live in times of erosion of these values rather than in times of their endorsement (and we can question whether this process has something to do with the so-called "populism") - how to build a sense of European identity on something that many member states themselves probably do not believe in?

\section{Shared Economic Interests}

Shared economic interests can be the second "candidate" for identity building - sense of belonging is closely connected with material self-interests of people. In the case of EU it means to build pragmatically on what has been already achieved (or is perceived as a near future goal to be achieved) in the EU economic and social level, like the common market, absence of border controls or common currency. Because this concept is based on the people's self-interests, it does not demand for stronger moral commitments - as long as the EU benefits them, people will continue to share the common European identity, but not a single moment longer. In a similar way as the first common values model, economic pragmatism does not offer us any "thick" identity inclusive enough to compete e.g. with nationalist models - in a famous phrase of Ernst Renan "Zollverein n'est pas la patrie" and in a Monnet's phrase "no one falls in love with a common market".

It may be true that today many people do not perceive such EU achievements as a common currency or absence of border controls as per se advantages - e.g. some can say that possibility to devaluate national currency could "save" Greeks or other rather non-competitive economies from the worst moments in times of financial crisis, others are maybe 
right to think that it was exactly the wrongly fixed exchange rate of their national currency to euro that have created incentives for these rather non-competitive economies to spend more (typically on wages or social benefits) than they can really afford. In a similar way the migration crisis started to question the openness of borders and free movement of persons can be questioned by those who particularly do not like the "influx" of many "new" member states workers to "old" member states etc.

But in my opinion the biggest problem of economic pragmatism was caused by erosion of something that could be perceived as a unique and truly European "invention" - its welfare state model. We cannot forget that the idea of capitalism in Europe after the Second World War had its social dimension and that period of twenty post-War years was perhaps the most optimistic time, when especially economic policy that can be called "social democratic" (practiced even by conservative political parties) ensured the steady increase of living standards. The German economic sociologist Wolfgang Streeck in my opinion clearly showed that in a period between 1968 and 1971 this "deal" between capitalism and democracy (that was more or less caused by the fact that soldiers returning from the war realized that capitalists came out from the World War richer than before it, which brought a "deal" between both parties that prevented radicalness on both sides) had broken, trade and labour movements started to decline and capital was finally unleashed - since these times capital is a dominant political agent once again and labour started to lose its political role. To make long story short, while in the end of 1960s (after building of main welfare state pillars) the conflicting interests of markets and workers were "solved" by rising inflation, economic crisis of 1970s provoked campaign against high inflation and the problem of democratic capitalism was "solved" by rising public debt. The beginning of 1990s was marked by a campaign against increasing public debt that in turn leads to the next "solution", how to save a "deal" between capitalism and democracy - private debt. And the rise of private debt has provoked the last financial crisis that started as 2008 US sub-prime mortgages crisis and soon turned to a Eurozone crisis and austerity policies of our recent years. ${ }^{13}$ At the same time the beginning of 1970s started the financialisation of services (the process of dominance of economy by finance industry), monetary policies became the key governing tool and it is within this context we have to perceive also the introduction of common currency in the EU and famous "Maastricht criteria" - in other words, not necessar-

13 For more developed, yet still short version of this "story" see: e.g. W. Streeck, The Crises of Democratic Capitalism, "New Left Review”, vol. 71, September-October 2015, pp. 5-29. 
ily in "service" of labour, but rather in "service" of financialisation. No wonder that the common currency had to be saved almost at all costs and in this context it makes a perfect sense to deprive the voters of debtor nations of their right to change economic policy despite retaining a capacity to change governments - does the political value of democracy in this context still make any sense? ${ }^{14}$ And if almost ten years of financial crisis (that started in 2008) did not stop or slow the rise of global concentration of wealth in hands of even smaller number of agents, ${ }^{15}$ why people not only in Europe would expect that there are some shared economic interests between them and global capital?

To sum up, it is highly questionable whether it is possible today to reintroduce the European model of welfare state and to tame global inequality of wealth at least on the EU level, given that instruments suggested (like global tax on financial transactions ${ }^{16}$ or fight against global tax loopholes ${ }^{17}$ ) are highly improbable to materialize (because not even the EU alone can do anything substantial on a global level) and more participative capitalism looks almost like an utopia. ${ }^{18}$ Why should Europeans believe in advantages of European integration, if this integration cannot deliver them the analogy of post-war prosperity?

14 See e.g.: R. Lambert, S. Leder, En Italie et en Turquie comme ailleurs, les gouvernements cèdent aux marchés; Linvestisseur ne vote pas. "Le monde diplomatique", July 2018, pp. 18 et seq.

15 See e.g.: T. Piketty, G. Zucman, Capital is back: Wealth-income ratios in rich countries, 1700-2010, "Quarterly Journal of Economics”, vol. 129/2014, pp. 1255-1310. This article shows that that the ratio between private wealth and national income was in USA, France, Germany and UK during 18th and 19th centuries 600-700 per cent, then decreased to 200-300 per cent in 1970 and from this year has started to grow once again to $400-600$ in 2010.

16 See e.g.: F. Lemaire, En attendant la taxe Tobin. "Le monde diplomatique", may 2016.

17 G. Zucman, The Hidden Wealth of Nations: The Scourge of Tax Havens, ChicagoLondon 2015.

18 See e.g.: R. Varghese, Marxist World, "Foreign Affairs", no. 4/2018, p. 42: “As the crisis of the golden age was ramping up in the 1970s, the economist James Meade wondered what sorts of policies could save egalitarian, social democratic capitalism, recognizing that any realistic answer would have to involve moving beyond the limits of Keynesianism. His solution was to buttress the welfare state's redistribution of income with a redistribution of capital assets, so that capital worked for everyone. Meade's vision was not state ownership but a broader property-owning democracy in which wealth was more equally distributed because the distribution of productive capacity was more equal.“ Does anybody really think that e.g. the fact that Uber driver is the owner of her own car (capital asset) protects her from possible exploitation? 


\section{Shared Culture}

If political values model and economic pragmatism model could offer us only weak and "thin" conceptions of identity, the model based on shared culture (European cultural heritage) is promising more robust or "thick" version of identity. But this model suffers from an almost insurmountable problem of the diversity of Europe's languages, cultures and traditions which makes it highly problematic or even impossible to be a ground for the common identity. ${ }^{19}$ Some would propose our common Christian roots as a shared identity, but we must not forget that it is perhaps rather secularization (not only in a political sense, but first of all in our social practices) that is a distinctive feature of European society compared with the rest of the world. ${ }^{20}$ Others would point to the common heritage of Athens, Rome or Jerusalem, Renaissance (which itself, in my view, was very different e.g. in Italy, Germany or in the Netherlands) or Enlightenment (but again, there are not-negligible differences between German Aufklärung that is easily compatible with monarchical absolutism, British Enlightenment that does not believe in abstractions but only in empirical knowledge and French Lumiéres who were sensualists and mechanicists that in the name of abstract ideas stimulated the revolution). And there is still a strong tradition of nation-state (in spite of the well-known difference between civic nationalism and "ethnic" or volkish nationalism) that was from a historical perspective a very important and rather successful idea until the post-war era, when it was exactly the very idea of European integration that put the nation-state concept into a rather ambiguous light - on the one hand we perceive the European integration project as overcoming of nation-states in "ever closer union", and on the other hand "Europe of nations" can be perceived as a legitimate and viable alternative to this overcoming.

Given these differences between various European cultures it is not surprising that this situation of plurality can be perceived by some people as a very basis of European identity - we are Europeans, because we are "united in our diversity", because "one of the features of European history has been the constant negotiation of difference; the existence of bor-

19 It is clear that if Europe is understood as a cultural "area", then it does not necessarily coincide with EU - can anybody really think that after Brexit Britain will cease to be the part of Europe? Neither it is possible to define Europe as a territory, nor to find out its borders.

20 According to e.g. English sociologist of religion Grace Davie secularism is what distinguish European society from US, African or Latin American societies. See: G. Davie, Europe: The Exceptional Case. Parameters of Faith in the Modern World, London 2002. 
derlands; the reinvention of the past". ${ }^{21}$ There is thus a possibility of truly cosmopolitan culture that does not negate our traditions and memories, but rather embraces plurality of thinner or thicker cultural layers overlapping each other, approach that celebrates "the ability to see the other within the self and oneself as other". ${ }^{22}$ The cosmopolitan aspect of this concept lies in its openness towards others in the form of emancipation of potentially everybody (potentially every "other" could be included be it Muslim or Jew, citizen of member state or so-called denizen), of anti-racism and "inclusion of marginal voices". It therefore emphasizes the possibility of non-identity as a feature of identity construction - "the other" is not subjected, eliminated or cleansed, but it is a part of the identity itself.

I think that from the presentation of this "identity in diversity" model it is clear that it is the "product" of the 1990s or the beginning of this century - "product" of times before 9/11 and the US adventure in Iraq (that can be perceived as triggering moment of a present-day Middle East disintegration and thus of migration crisis too), when many still optimistically accepted the idea of "end of history", believed in "one-way" character of European integration and postmodern thinkers (inspired typically by Derrida or Lévinas) offered us inclusion of the "other" without her necessary subjection, "happy" multiculturalism (accompanied on the level of law by constitutional or legal pluralism) etc. In present-day reality, however, when many people think that multiculturalism is at least a questionable approach (that in many European cities has not produced pluralistic and open societies, but rather "ghettos" full of "others" on the one side and compounds for the rich on the other), the question of security (job security, food security, energy security etc.) is shaping almost all of our discussions and worries and fears are governing our lives, ${ }^{23}$ then complex abstract constructions about inclusion of "other" is perceived by the general public as something between "moral luxury" and "mumbo jumbo" of intellectuals detached from the "real life" problems.

To put it clearly: I do not think that there is a "way back" to ethnic nationalisms, close borders and isolationism in Europe and I personally support the idea of cosmopolitan Europe based on "constant negotiation of difference" and "reinvention of the past" as the only way how to man-

${ }^{21}$ G. Delanty, Models of European Identity: Reconciling Universalism and Particularism, "Perspectives on European Politics and Society", no. 3/2002, p. 354.

22 Ibidem.

23 If migrants are causing fear (terror in Latin) among general public not only in Central and Eastern European countries, no wonder that they are very easily assimilated with terrorists. 
age multicultural society we are living in (or, seen from Central Europe, will be living in a foreseeable future). But at the same time I think that material conditions for the creation of this "fragile" or "delicate" identity model must be created in some form of reinvented welfare state that could liberate us from paralyzing fear and enable us to start a dialogue with "real others" from different cultures in our every-day lives. But if the idea of EU "social dimension" is rather a matter of words than deeds and prosperity is rather a dream of the past, no wonder that so many people do not see a light in the end of a tunnel.

\section{Instead of Conclusion}

In his recent book the Bulgarian political scientist Ivan Krastev has presented, inter alia, an image of "browning Europe": "Whereas populists contend that our societies are ,browning' by being, polluted' by nonwhite races, cultures and religions and that Europe is unable or unwilling to defend its values, liberals fear that societies are, browning' but in the sense that a growing number of people share the ideology of brownshirts of National Socialist Germany". ${ }^{24}$ Maybe it is possible to say that Europe today resembles a brownfield, not in its original sense of a landscape polluted and destroyed by past industrial activities, but rather in a figurative sense of "brownfield of ideas" - no new ideas for Europe's future, no new receipts how we can handle our crises, only buying time and preparing documents and plans that can turn, sooner or later and very easily, into a scrap.

In the beginning of the same book Krastev uses the disintegration of Central European Habsburg Empire as an example helping us to imagine the possible disintegration of the EU. "I am someone who believes that the disintegration train has left Brussels's station - and who fears it will doom the continent to disarray and global irrelevance. It will likely transform a sympathetic environment of tolerance and openness to one characterized by a bullying narrow-mindedness. It may cause the breakdown of liberal democracies on Europe's periphery and usher in the collapse of several existing member states. It will not necessarily lead to war, but it will probably contribute to misery and turmoil. Political, cultural and economic cooperation won't evaporate, but the dream of Europe free and united probably will". ${ }^{25}$ If this or similar vision of disintegration can materialize, then experience of those that have already suffered from similar collapses can be instructive - which can lead us to specific Central Euro-

24 I. Krastev, After Europe, Philadelphia 2017, p. 39.

25 Ibidem, p. 10. 
pean experience. It is hard to describe this experience in exact terms, but if it really matters, it materializes itself in a cultural level, maybe in great novels: Can be Musil's description of "parallel action" in Man Without Qualities, whose hopeless task was to find the idea for Kakania, compared to present-day task to find idea of Europe? Can we read Broch's three reactions to disintegration of values in Sleepwalkers as an example how questioning of our present-day values could end up? Etc.

The Czech novelist Milan Kundera in his book published originally already in 1986 wrote the following words about modern Europe: "In the Modern Era, religion yielded its position to culture (to cultural creation), which came to embody the supreme values by which Europeans recognized themselves, defined and identified themselves. Now, in our own time, culture is in turn yielding its position. But to what and to whom? What sphere will provide the sort of supreme values that could unify Europe? Technology? The marketplace? Politics involving the democratic ideal, the principle of tolerance? But if that tolerance no longer has any rich creativity or any powerful thought to protect, will it not become empty and useless? Or can we take culture's abdication as a kind of deliverance, to be welcomed euphorically? I don't know. I merely believe that culture has already yielded. And thus the image of European unity slips away into the past. European: one who is nostalgic for Europe". ${ }^{26}$

If Kundera is right and "the novel is Europe's creation; its discoveries though made in various languages, belong to the whole Europe", ${ }^{27}$ if novel is "the great prose in which an author thoroughly explores, by means of experimental selves (characters), some great themes of existence", ${ }^{28}$ and if this existential moment is usually manifested in laugh, when "we do not laugh because somebody is ridiculed or even humiliated, but because a reality abruptly is uncovered in its ambiguity, things are losing their apparent signification, the man just before our eyes is not what he thinks to be", ${ }^{29}$ then there is no necessity to mourn our present-day situation laugh as a sign of revelation of our existence as characters in a truly European novel can be our "proper" European reaction.

\footnotetext{
26 M. Kundera, The Art of the Novel, London 1990, p. 127 et seq.

27 Ibidem, p. 6.

28 Ibidem, p. 142.

29 M. Kundera, Le rideau, Paris 2005, p. 134.
} 


\section{References}

Alexy R., Lidská di̊stojnost a princip proporcionality (Human Dignity and Proportionality Principle), „Právník”, no. 11/2015, p. 873 et seq.

Davie G., Europe: The Exceptional Case. Parameters of Faith in the Modern World, London 2002.

Delanty G., Models of European Identity: Reconciling Universalism and Particularism, „Perspectives on European Politics and Society”, no. 3/2002.

Faure S., Alonso P., Etat d'urgence: des travers dans l'Etat de droit, "Liberation", 21st of June 2017.

Habermas J., Toward a Cosmopolitan Europe, "Journal of Democracy", no. 4/2003, pp. 86-100.

Held D., Models of Democracy, 3rd edition, Cambridge 2006.

Krastev I., After Europe, Philadelphia 2017, https://doi.org/10.9783 /9780812294262.

Kundera M., Le rideau, Paris 2005.

Kundera M., The Art of the Novel, London 1990.

Lambert R., Leder S., En Italie et en Turquie comme ailleurs, les gouvernements cedent aux marches; Linvestisseur ne vote pas, "Le monde diplomatique", July 2018.

Laskey, Faggard and Brown v UK (1997) 24 EHRR 39.

Lemaire F., En attendant la taxe Tobin. "Le monde diplomatique", may 2016.

Omega Spielhallen- und Automatenaufstellungs-GmbH v. Oberburgermeisterin der Bundesstadt Bonn [2004] ECR I-09609 C-36/02.

Piketty T., Zucman G., Capital is back: Wealth-income ratios in rich countries,1700-2010, "Quarterly Journal of Economics”, vol. 129/2014, pp. 1255-1310.

Šejvl M., European Identity and European Citizenship: the Case of Missing Polis?, "International Journal of Public Administration in Central and Eastern Europe", no. 2/2008, pp. 49-56.

Šejvl M., Lidská práva jako diskursioní pojem (Human Rights as an Essentially Contested Concept), „Právník”, no. 6/2017, pp. 473-500.

Streeck W., The Crises of Democratic Capitalism, „New Left Review”, vol. 71, September-October 2015, pp. 5-29.

Szente Z., Gárdos-Orosz F., Fudicial deference or political loyalty?: The Hungarian Constitutional Court's role in tackling crisis situations, in: New Challenges to Constitutional Adjudication in Europe. A Comparative Perspective, eds. Z. Szente, F. Gárdos-Orosz, London 2018, pp. 89-110, https://doi. org/10.4324/9781315164632-7.

Varghese R., Marxist World, "Foreign Affairs”, no. 4/2018.

Zucman G., The Hidden Wealth of Nations: The Scourge of Tax Havens, Chicago-London 2015. 